\title{
SINTESIS DAN KARAKTERISASI ZEOLIT MORDENIT (MOR) PORI HIRARKI BERBASIS SILIKA ABU AMPAS TEBU
}

\author{
Mita Rilyanti", Ella Gita Silviana, Buhani, Kamisah D. Pandiangan, Ni Luh Gede Ratna Juliasih \\ Jurusan Kimia, Fakultas Matematika dan Ilmu Pengetahuan Alam, Universitas Lampung \\ mita.rilyanti@fmipa.unila.ac.id
}

Artikel Info
Diterima tanggal
14.03 .2020
Disetujui
publikasi tanggal
30.10 .2020
Kata kunci :
solid-State
crystallization,
kristalin, pori
hirarki, zeolit
mordenit,

Artikel Info

Diterima tanggal

Disetujui

publikasi tanggal

Kata kunci :

solid-State

crystallization,

kristalin, pori

hirarki, zeolit

.

\begin{abstract}
ABSTRAK
Pada penelitian ini dilakukan sintesis zeolit mordenit (MOR) pori hirarki berbahan dasar silika abu ampas tebu (Sugarcane Bagasse Ash/SCBA) menggunakan metode Solid-State Crystallization (SSC). Penelitian ini diawali dengan ekstraksi silika dari SCBA menggunakan pelarut alkali $(\mathrm{NaOH})$ dan silika hasil ekstraksi digunakan sebagai sumber silika sekaligus sumber alumina untuk mensintesis zeolit MOR pori hirarki. Sebagai pembanding, zeolit MOR pori hirarki juga disintesis menggunakan silika komersial. Sintesis zeolit MOR pori hirarki dilakukan pada suhu $170{ }^{\circ} \mathrm{C}$ selama 120 jam. Difraksi sinar-X menginformasikan bahwa silika yang diekstraksi dari SCBA memiliki fasa amorf dan analisis FTIR menunjukkan adanya gugus silanol dan siloksan dengan kandungan silika dan alumina sebesar 85,55 dan $12,16 \%$ berdasarkan analisis XRF. Hasil analisis XRD menunjukkan bahwa zeolit MOR pori hirarki yang disintesis menggunakan silika SCBA maupun silika komersial (LUDOX) memiliki fasa kristalin dengan puncak-puncak yang karakteristik untuk zeolit MOR dengan ukuran pori sebesar 4,84 nm.
\end{abstract}

\section{ABSTRACT}

In this research, the synthesis of MOR pore hierarchy is based on sugarcane bagasse ash (SCBA) using Solid-State Crystallization (SSC) method. This research was begun with the extraction of silica from SCBA using an alkaline solvent $(\mathrm{NaOH})$ and the extracted silica was used as a source of silica as well as an alumina source to synthesize zeolite porous MOR zeolites. As a comparison, zeolite MOR pore hierarchy is also synthesized using commercial silica. Synthesis of zeolite MOR pore hierarchy was carried out at $170{ }^{\circ} \mathrm{C}$ for 120 hours. The characterization results inform that the silica extracted from SCBA has an amorphous phase and shows the presence of silanol and siloxan groups with silica and alumina contents of 85.55 and $12.16 \%$. The results of the XRD analysis showed that the porous HOR zeolite was synthesized using SCBA silica and commercial silica (LUDOX) having a crystalline phase with peaks characteristic for MOR zeolites with a pore size of $4.84 \mathrm{~nm}$.

\section{PENDAHULUAN}

Zeolit adalah material kristalin aluminosilikat berpori, yang memiliki stabilitas hidrotermal yang sangat baik dan telah digunakan dalam berbagai bidang industri kimia seperti pertukaran ion, adsorpsi, pemisahan dan sebagai katalis yang selektif (Chen et al. 2012; Zhu et al. 2011; Cao and Shah 2007). Zeolit dapat diperoleh secara alami dari alam atau disintesis dari

doi: http://dx.doi.org/10.23960/aec.v5.i2.2020.p178-191

Anal.Environ.Chem. 
pereaksi kimia dengan berbagai metoda. Zeolit sintetik lebih banyak digunakan dibanding zeolit alam karena kemurnian dan keseragaman ukuran partikelnya yang lebih baik. Metoda sintesis yang umum digunakan adalah hidrotermal, solvotermal, konversi gel kering (DGC, Dry-Gel Conversion) dan teknik ionotermal (Alfaro et al. 2009; Zhou et al. 2009; Wang et al. 2013).

Sintesis hidrotermal merupakan metoda yang paling sering digunakan untuk preparasi zeolite, melibatkan sejumlah besar pelarut air (Zhou et al. 2013). Meskipun biasanya air dianggap sebagai pelarut yang tidak berpolusi, penggunaan secara berlebihan dalam proses industri menghasilkan masalah seperti polusi berupa air limbah, penggunaan suhu dan tekanan yang relatif tinggi dan produk yang dihasilkan relatif rendah (Cheng et al. 2014; Rilyanti et al. 2016). Permasalahan penggunaan air dalam jumlah besar dalam sintesis zeolit dapat diatasi dengan melakukan sintesis menggunakan metoda Solid-State Crystallization, SSC (Wang et al. 2017). Metoda SSC merupakan metode sintesis zeolit yang banyak digunakan untuk bahan-bahan anorganik bersuhu tinggi, metode ini sering disebut dengan metode kering. Pada metode SSC reaksi padatan terjadi antar partikel yang bereaksi di atas permukaan, yang dipengaruhi oleh sifat kehomogenan bahan, tekanan saat kompaksi dan suhu sintering. Metode ini dapat digunakan sebagai metode alternatif untuk sintesis zeolit MOR. Penelitian sebelumnya Wang et al. (2017) telah mensintesis Zeolite Socony Mobile-5 (ZSM-5) dari silika komersial yaitu tetraetil ortosilikat (TEOS) menggunakan metode Solid-State Crystallization, prekursor gel diubah menjadi gel kering melalui proses evaporasi. Sejumlah air yang terperangkap dalam gel kering dapat membantu proses kristalisasi zeolit.

Zeolit mordenit (MOR) merupakan jenis zeolit dengan rasio Si/Al bernilai 5. Mordenit banyak muncul sebagai mineral di alam, tetapi zeolit mordenit sintetik lebih banyak dikembangkan dikarenakan kemurniannya yang lebih tinggi sehingga cocok digunakan dalam reaksi katalitik. Zeolit mordenit banyak berperan sebagai molekul penyaring (molecular sieve) dalam proses adsorbsi yang melibatkan komponen asam namun dalam perkembangannya zeolit mordenit banyak digunakan sebagai katalis seperti dalam proses alkilasi, isomerisasi, reforming dan cracking (Cheng et al. 2014).

Sementara itu berdasarkan data statistik Indonesia tahun 2017, Direktorat Jenderal Perkebunan menginformasikan bahwa luas lahan tebu di daerah Lampung pada tahun 2017 sekitar 12.023 ha dan produksi tebu untuk daerah Lampung berkisar 64.171 ton/tahun (Perkebunan 2017)

doi: http://dx.doi.org/10.23960/aec.v5.i2.2020.p178-191 
. Hasil tanaman tebu digunakan sebagai bahan baku pada industri gula dan menghasilkan ampas tebu sebagai limbah dalam jumlah yang besar (Hajiha et al. 2015). Sebagian ampas tebu digunakan sebagai bahan bakar pada boiler dan sisanya sebagai limbah padat yang belum termanfaatkan (PayÃ $\tilde{i}_{i}$ et al. 2002). Menurut Hajiha et al. (2015), abu ampas tebu mengandung 60-70\% silika. Kandungan silika yang cukup tinggi dalam abu ampas tebu memberi peluang untuk dimanfaatkan sebagai sumber silika dalam sintesis zeolite mordenit (MOR). Dengan demikian pada penelitian ini dilakukan sintesis zeolit mordenit pori hirari menggunakan metoda SSC menggunakan silika yang diekstraksi dari abu ampas tebu (Sugarcane Bagasse Ash, SCBA). Sebagai pembanding zeolit MOR juga disintesis menggunakan silika komersial LUDOX. Penelitian diawali dengan ekstraksi silika dari abu ampas tebu menggunakan pelarut alkali $(\mathrm{NaOH})$ dan pembentukan gel dilakukan dengan penambahan asam nitrat. Silika hasil ekstraksi dikarakterisasi menggunakan $X$ Ray Diffraction (XRD), Fourier Transform Infrared (FTIR) dan X-Ray Fluorescence (XRF), sedangkan zeolit hasil sintesis dikarakterisasi menggunakan XRD, Brunauer-Emmett-Teller (BET), Scanning Electron Microscopy (SEM).

\section{METODE}

\section{Alat dan Bahan}

Bahan-bahan yang digunakan dalam penelitian ini yaitu ampas tebu dari PT. Adi Karya Gemilang di Terbanggi Besar, silika komersial LUDOX (40 wt\%), asam nitrat $\left(\mathrm{HNO}_{3} 2,5\right.$ dan $10 \%$ ), $\mathrm{NaOH} 2 \mathrm{M}$, kertas saring, aquades, indikator universal, $\mathrm{NaOH} 50 \%$ (w/w).

Alat-alat yang digunakan dalam penelitian ini yaitu neraca analitik (Kern and Sohn gmbh abt 220-4m), oven (innotech), gelas kimia $2000 \mathrm{ml}$ dan $1000 \mathrm{ml}$, gelas ukur $100 \mathrm{ml}$ dan $50 \mathrm{ml}$, spatula, termometer $100{ }^{\circ} \mathrm{C}$, corong kaca besar, loyang, hotplate stirrer suhu maksimal $400{ }^{\circ} \mathrm{C}$, erlenmeyer $250 \mathrm{ml}$, buret, statif dan klem, tanur (Heraeus), spinbar besar dan kecil, batang pengaduk, cawan penguap $250 \mathrm{ml}$, labu ukur $1000 \mathrm{ml}$, botol polipropilen, seperangkat autoklaf, pipet tetes, mortal dan alu. Karakterisasi sampel dilakukan menggunakan X-Ray Fluorescence (XRF) merek PANalytical Epsilon 3, X-Ray Diffraction (XRD) merek PANalytical, Nitrogen Sorption Isotherms merek Quantachrome Instruments, Scanning Electron Microscopy (SEM) merk ZEISS dan Spektrofotometer Fourier Transform Infrared (FTIR) merk Agilent Technologies. 


\section{Prosedur}

\section{Ekstraksi silika dari SCBA}

Preparasi ampas tebu dilakukan melalui proses pencucian dan pemanasan, dimana 10 gram ampas tebu dimasukkan ke dalam $250 \mathrm{~mL} \mathrm{HNO}_{3} 2,5 \%$ dipanaskan pada suhu $80{ }^{\circ} \mathrm{C}$ menggunakan pemanas sambil diaduk menggunakan batang pengaduk dan dibiarkan mendidih selama 1 jam. Ampas tebu yang telah dipanaskan, kemudian dibilas sampai filtrat bening dan disaring. Ampas tebu yang telah dicuci, selanjutnya dikeringkan menggunakan oven pada suhu $100{ }^{\circ} \mathrm{C}$.

Ampas tebu yang telah dipreparasi, dimasukkan ke dalam cawan penguap $250 \mathrm{~mL}$ dan dilakukan pembakaran menggunakan tanur pada suhu $600{ }^{\circ} \mathrm{C}$ selama 5 menit sampai didapatkan SCBA. Sebanyak 5 g SCBA, diekstraksi menggunakan 125 mL larutan NaOH 2 M dan dipanaskan menggunakan hot plate pada suhu $80{ }^{\circ} \mathrm{C}$ disertai pengadukan sampai mendidih selama 1 jam. Campuran dibiarkan pada suhu kamar selama 24 jam, kemudian disaring menggunakan kertas saring hingga diperoleh filtrat berwarna kuning kecoklatan. Filtrat ditambahkan larutan $\mathrm{HNO}_{3}$ $10 \%$ tetes demi tetes hingga terbentuk hidrogel pada $\mathrm{pH} 7$ dan hidrogel dibiarkan selama 48 jam hingga terbentuk gel. Gel disaring menggunakan kertas saring dan dicuci menggunakan aquades, lalu gel dikeringkan menggunakan oven pada suhu $80{ }^{\circ} \mathrm{C}$ selama 24 jam hingga menjadi silika. Silika yang didapatkan selanjutnya dikarakterisasi dan dijadikan sebagai prekursor untuk sintesis MOR pori hirarki.

\section{Karakterisasi silika hasil ekstraksi}

Karakterisasi silika dilakukan menggunakan analisis XRF untuk mengetahui komposisi senyawa pada silika SCBA, analisis FTIR untuk mengetahui gugus fungsi penyusun kerangka silika SCBA, analisis XRD dilakukan untuk mengetahui jenis fasa dan tingkat kristalinitas dari silika SCBA, dan SEM untuk melihat morfologi permukaan silika SCBA.

\section{Sintesis zeolit MOR pori hirarki}

Sintesis zeolit mordenit dilakukan menggunakan sumber silika dari SCBA dan sebagai pembanding sintesis dilakukan menggunakan sumber silika komersial berupa LUDOX. Sintesis MOR dilakukan dengan perbandingan molar pereaksi $1 \mathrm{SiO}_{2}: 0,229 \mathrm{NaOH}: 80 \mathrm{H}_{2} \mathrm{O}: 0,284$ 
$\mathrm{NaAlO}_{2}$ (Wang et al., 2017). seluruh prekursor dicampurkan dan diaduk menggunakan pengaduk magnetik di atas hotplate pada suhu $80{ }^{\circ} \mathrm{C}$ sampai terbentuk gel kering (dry gel). Gel kering dihaluskan hingga menjadi serbuk. Serbuk gel kering dimasukkan ke dalam autoklaf berlapis teflon tanpa penambahan pelarut air maupun etanol (kristalisasi secara SSC) pada suhu $170{ }^{\circ} \mathrm{C}$ selama 120 jam. Crude produk dicuci menggunakan aquades dan dikeringkan pada suhu $80{ }^{\circ} \mathrm{C}$ selama 4 jam. Sebagai pembanding, sintesis zeolit MOR pori hirarki berbasis silika abu ampas tebu dilakukan secara SSC (Rilyanti et al. 2016).

\section{Karakterisasi zeolit MOR pori hirarki}

Zeolit MOR pori hirarki yang disintesis menggunakan silika SCBA dan silika komersial telah dikarakterisasi dengan menggunakan beberapa analisis, yaitu menggunakan analisis XRD untuk mengetahui fasa dan tingkat kristalinitas zeolit, analisis SEM untuk mengetahui morfologi permukaan zeolit, analisis FTIR untuk mengetahui gugus fungsi zeolit, dan analisis nitrogen sorption isotherms menggunakan metode Brunauer-Emmett-Teller (BET) untuk mengetahui luas permukaan dan diameter pori-pori zeolit.

\section{HASIL DAN PEMBAHASAN}

\section{Ekstraksi silika dari SCBA}

Ampas tebu yang sudah bersih dan kering tersebut dibakar menggunakan tanur pada suhu $600^{\circ} \mathrm{C}$ untuk menghasilkan abu ampas tebu (sugarcane bagasse/ SCB). Pembakaran bertujuan untuk mengubah senyawa organik berupa selulosa, hemiselulosa, dan lignin dalam ampas tebu menjadi karbon yang kemudian dapat dipisahkan melalui penyaringan. Penghilangan senyawa organik dalam ampas tebu memudahkan proses ekstraksi sehingga didapatkan silika dengan kemurnian yang tinggi (Hajiha et al. 2015).

Silika dapat larut dalam alkali, sehingga ekstraksi silika dilakukan dengan menggunakan larutan alkali $\mathrm{NaOH}$, dimana $\mathrm{NaOH}$ memiliki alkalinitas yang tinggi sehingga meningkatkan kelarutan silika (MoisÃ@s et al. 2014; PayÃ $i$ et al. 2002). Silika xerogel dengan kemurnian tinggi dapat dihasilkan dari abu ampas tebu menggunakan $\mathrm{pH}$ gelasi 7-8 dengan waktu aging 18 jam, sehingga silika gel (hidrogel) diendapkan menggunakan larutan asam nitrat $\left(\mathrm{HNO}_{3}\right) 10 \%$ sampai $\mathrm{pH} 7$.

doi: http://dx.doi.org/10.23960/aec.v5.i2.2020.p178-191 
Pencucian hidrogel menggunakan aquades bertujuan untuk membersihkan hidrogel dari sisa-sisa filtrat, sehingga gel silika yang didapat menjadi berwarna putih. Padatan silika didapat berwarna putih yang ditunjukkan pada Gambar 1.

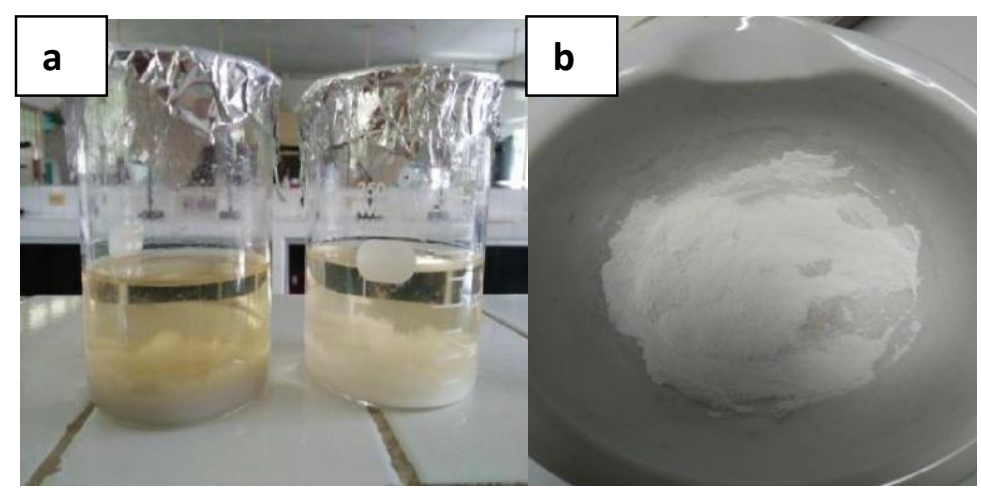

Gambar 1. Hidrogel silika (a) dan padatan silika hasil ekstraksi (b).

Persentase rendemen silika yang dihasilkan dari ekstraksi SCBA yaitu 6,52\% berdasarkan perhitungan berikut ini.

$$
\mathrm{RS}=\frac{B S}{B A} x 100 \%
$$

$\mathrm{RS}=$ rendemen silika (\%), BS=berat silika $(\mathrm{g})$, dan BA=berat abu ampas tebu $(\mathrm{g})$

\section{Karakterisasi silika hasil ekstraksi}

Pembakaran ampas tebu menyebabkan penurunan jumlah senyawa organik dan senyawa volatil lain sehingga mengakibatkan terjadinya kristalisasi fasa amorf (Mois ̃̃@s et al. 2014). Pola difraksi hasil analisis XRD dari silika SCBA dapat dilihat pada Gambar 2.

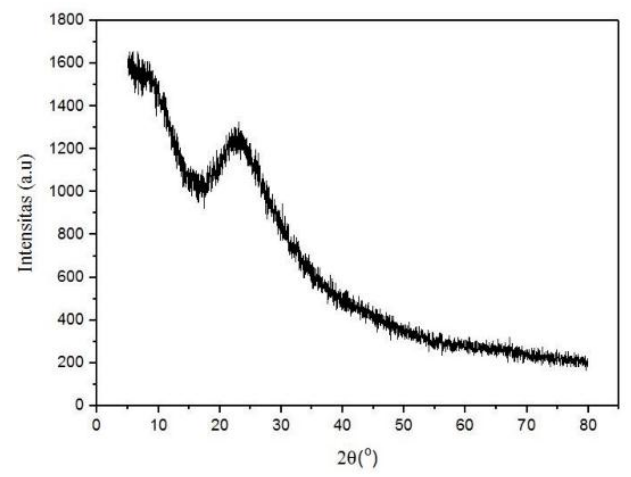

Gambar 2. Difraktogram silika SCBA.

Bentuk pola difraksi yang melebar (Gambar 2) dan khas dari padatan amorf menunjukkan bahwa silika yang diekstraksi berfasa amorf yang dikonfirmasi dengan tidak adanya puncak 
kristalin. Hasil analisis XRF ditunjukkan pada Tabel 1, rasio Si/Al dari silika SCBA diperoleh sebesar 3,51.

Tabel 1. Komposisi kimia dalam silika hasil ekstraksi.

\begin{tabular}{cc}
\hline Komponen & Konsentrasi (\%) \\
\hline $\mathrm{MgO}$ & 0,282 \\
$\mathrm{Al}_{2} \mathrm{O}_{3}$ & 12,162 \\
$\mathrm{SiO}_{2}$ & 85,552 \\
$\mathrm{P}_{2} \mathrm{O}_{5}$ & 1,508 \\
$\mathrm{Cl}$ & 0,008 \\
$\mathrm{~K}_{2} \mathrm{O}$ & 0,026 \\
$\mathrm{CaO}$ & 0,246 \\
$\mathrm{Ti}$ & 0,003 \\
$\mathrm{Cr}$ & 0,001 \\
$\mathrm{Mn}$ & 0,001 \\
$\mathrm{Fe}_{2} \mathrm{O}_{3}$ & 0,107 \\
$\mathrm{Zn}$ & 0,041 \\
$\mathrm{Ga}$ & 0,001 \\
$\mathrm{Ag}$ & 0,060 \\
$\mathrm{Ba}$ & 0,002
\end{tabular}

Hasil analisis XRF menunjukkan silika SCBA mengandung Si dan Al, analisis FTIR akan mengkonfirmasi adanya gugus silanol $(\mathrm{Si}-\mathrm{OH})$ dan siloksan $(\mathrm{Si}-\mathrm{O}-\mathrm{Si})$ pada silika SCBA. Spektra FTIR dari silika SCBA ditunjukkan pada Gambar 3.

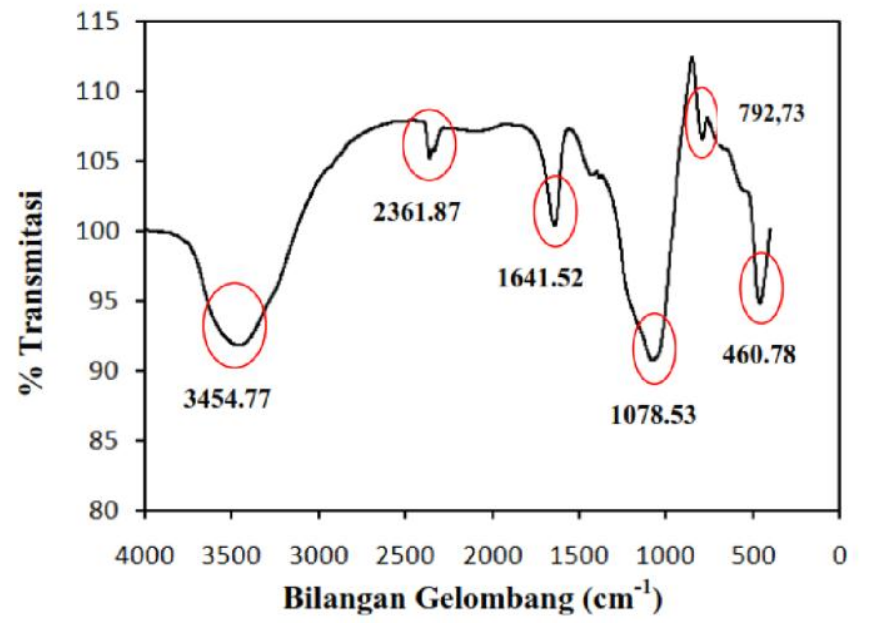

Gambar 3. Spektra FTIR silika SCBA.

Pita serapan yang melebar pada bilangan gelombang $3500 \mathrm{~cm}^{-1}$ disebabkan oleh vibrasi regangan dari ikatan $\mathrm{OH}$ dari gugus silanol $(\mathrm{Si}-\mathrm{OH})$ yang dihasilkan oleh molekul air yang terserap pada permukaan silika, berdasarkan Gambar 3, silika SCBA memiliki gugus silanol 
ditunjukkan pada bilangan gelombang $3454,77 \mathrm{~cm}^{-1}$. Pita serapan pada 1060 hingga $1100 \mathrm{~cm}^{-1}$ disebabkan oleh vibrasi asimetris dari ikatan siloksan ( $\mathrm{Si}-\mathrm{O}-\mathrm{Si})$. Pita serapan pada bilangan gelombang $1090 \mathrm{~cm}^{-1}$ menunjukkan adanya vibrasi simetris dan asimetris internal dari -OT-O (T $=\mathrm{Si}, \mathrm{Al}$ ) (Norsuraya et al. 2016), pita serapan pada bilangan gelombang $1641,52 \mathrm{~cm}^{-1}$ dan muncul pita serapan pada bilangan gelombang $1078,53 \mathrm{~cm}^{-1}$ menunjukkan adanya vibrasi asimetri dari gugus siloksan pada silika SCBA.

Pita serapan pada bilangan gelombang $630-920 \mathrm{~cm}^{-1}$ merupakan vibrasi simetris dari ikatan $\mathrm{Si}-\mathrm{O}-\mathrm{Si}$, sedangkan pita serapan pada bilangan gelombang $460-480 \mathrm{~cm}^{-1}$ dikaitkan dengan vibrasi tekuk ikatan $\mathrm{O}-\mathrm{Si}-\mathrm{O})$. Pita serapan pada bilangan gelombang $791 \mathrm{~cm}^{-1}$ menunjukkan adanya vibrasi simetris dan asimetris internal dari-OT-O ( $\mathrm{T}=\mathrm{Si}, \mathrm{Al})$ (Worathanakul et al. 2009), pita serapan karakteristik gugus siloksi ( $\mathrm{Si}-\mathrm{O}-$ ) dari silika SCBA muncul pada bilangan gelombang $792,73 \mathrm{~cm}^{-1}$ yang menunjukkan adanya vibrasi simetri-OSi-O dan-OAl-O pada ikatan Si-O-Si dan Al-O-Al. Pita serapan juga muncul pada bilangan gelombang 460,78 $\mathrm{cm}^{-1}$ yang menunjukkan vibrasi tekuk dari $\mathrm{O}-\mathrm{Si}-\mathrm{O}$.

\section{Sintesis zeolit MOR pori hirarki}

Pembuatan dry gel sebagai tahap awal dalam metode SSC seperti yang dilaporkan oleh Wang et al. (2017) dilakukan dengan cara memanaskan prekursor gel pada suhu $60{ }^{\circ} \mathrm{C}$ untuk meningkatkan konsentrasi gel. Gel yang kering memiliki konsentrasi lebih tinggi dibandingkan dengan gel yang masih mengandung air, sehingga dengan tingginya konsentrasi akan mempercepat laju nukleasi dan kristalisasi dalam proses sintesis (Wang et al. 2017; Gao et al. 2019). Zeolit MOR hasil sintesis baik berbahan dasar silika SCBA maupun silika komersial (LUDOX) berwarna putih, seperti disajikan pada Gambar 4.

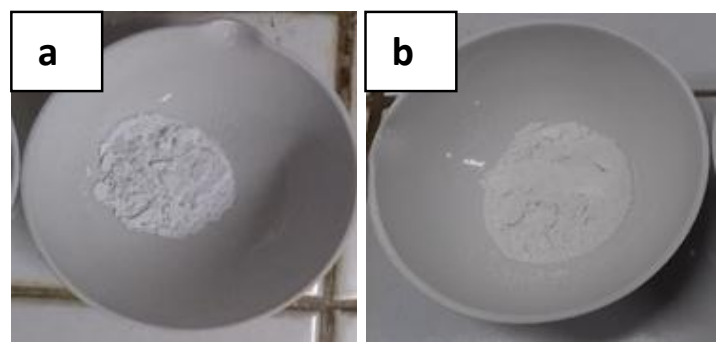

Gambar 4. Zeolit berbahan dasar (a) silika komersil dan (b) silika SCBA. 


\section{Karakterisasi zeolit hasil sintesis}

Pola difraksi zeolit MOR yang disintesis menggunakan silika SCBA dan LUDOX dapat dilihat pada difraktogram Gambar 5.

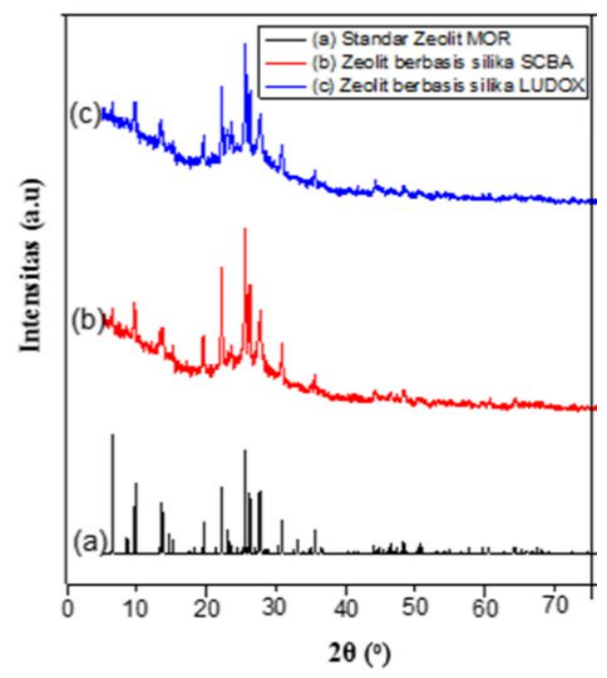

Gambar 5. Difraktogram zeolit MOR

Berdasarkan Gambar 5 dapat dilihat bahwa zeolit yang disintesis menggunakan silika SCBA dan LUDOX menunjukkan puncak-puncak khas untuk dari zeolit MOR dan memiliki tingkat kekristalan yang baik. Dengan demikian silika SCBA dapat digunakan sebagai prekursor untuk mensintesis mordenit. Pemanfaatan ampas tebu sebagai sumber silika dalam sintesis zeolit merupakan salah satu langkah yang sangat baik dalam mengurangi limbah padat industri gula. Zeolit yang dihasilkan merupakan material maju yang dapat digunakan sebagai katalis dalam berbagai reaksi kimia.

Analisis zeolit menggunakan SEM juga dilakukan untuk mengetahui morfologi permukaan dari zeolit MOR. Morfologi permukaan dari zeolit berbasis silika komersial (LUDOX) dan silika hasil ekstraksi (SCBA) ditunjukkan dalam mikrograf pada Gambar 6. 


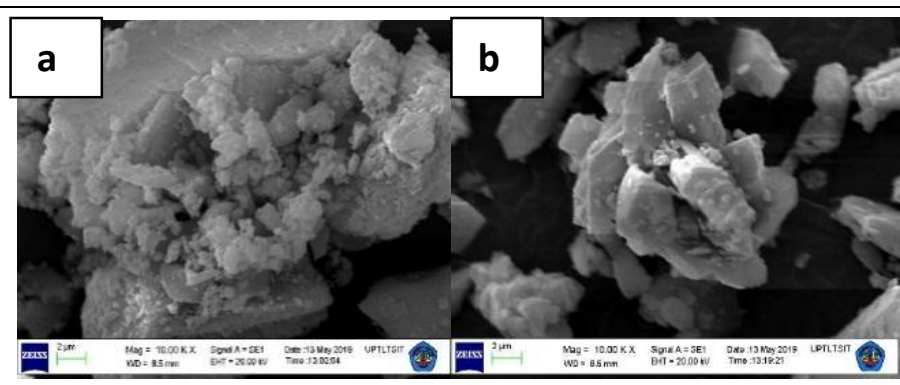

Gambar 6. Morfologi permukaan zeolit MOR hasil sintesis (a) berbasis silika komersil (LUDOX) (b) berbasis silika hasil ekstraksi (SCBA).

Berdasarkan Gambar 6 terlihat bahwa zeolit MOR berbasis silika LUDOX memiliki morfologi kristal yang menunjukkan adanya agregat berbentuk tak beraturan dengan ukuran partikel relatif kecil. Zeolit MOR berbasis silika SCBA memiliki morfologi kristal berbentuk tak beraturan dengan ujung relatif tajam dan berukuran tak seragam. Hasil analisis SEM ini sesuai seperti yang dilaporkan oleh Jin et al. (2012) dan Paix ̃̂£o et al. (2010) bahwa morfologi permukaan zeolit MOR berbentuk kristal dengan adanya agregat dengan ukuran relatif kecil.

Zeolit MOR berbasis silika komersial (LUDOX) dan silika hasil ekstraksi (SCBA) dikarakterisasi menggunakan XRF untuk mengetahui komposisi kimia pada kedua zeolit sehingga nilai rasio Si/Al juga dapat ditentukan. Komposisi kedua zeolit ditunjukkan pada Tabel 2.

Tabel 2. Komposisi zeolit berbasis silika komersial (LUDOX) dan silika hasil ekstraksi (SCBA)

\begin{tabular}{|c|c|c|}
\hline \multirow[b]{2}{*}{ Komponen } & \multicolumn{2}{|c|}{ Konsentrasi (\%) } \\
\hline & $\begin{array}{l}\text { MOR berbahan dasar silika } \\
\text { LUDOX }\end{array}$ & Zeolit berbasis silika SCBA \\
\hline $\mathrm{MgO}$ & 0,324 & - \\
\hline $\mathrm{Al}_{2} \mathrm{O}_{3}$ & 2,152 & 6,514 \\
\hline $\mathrm{SiO}_{2}$ & 96,303 & 91,480 \\
\hline $\mathrm{P}_{2} \mathrm{O}_{5}$ & 0,925 & 1,494 \\
\hline $\mathrm{Cl}$ & 0,027 & 0,011 \\
\hline $\mathrm{K}_{2} \mathrm{O}$ & 0,009 & 0,026 \\
\hline $\mathrm{CaO}$ & 0,150 & 0,302 \\
\hline $\mathrm{Ti}$ & 0,005 & 0,005 \\
\hline $\mathrm{Fe}_{2} \mathrm{O}_{3}$ & 0,032 & 0,050 \\
\hline $\mathrm{Zn}$ & 0,001 & 0,026 \\
\hline $\mathrm{Zr}$ & 0,007 & - \\
\hline $\mathrm{Ag}$ & 0,065 & 0,088 \\
\hline $\mathrm{V}$ & - & 0,001 \\
\hline
\end{tabular}


Rasio Si/Al dari zeolit berbasis silika LUDOX diperoleh 22,38 dan pada zeolit berbasis silika SCBA diperoleh 7,02. Rasio Si/Al kedua zeolit berubah dari 3,51 menjadi 22,38 pada zeolit berbasis silika LUDOX dan 7,02 pada zeolit berbasis silika SCBA setelah melalui proses sintesis. Hal ini menunjukkan bahwa tidak semua Al berpartisipasi dalam pembentukan kerangka zeolit, sehingga diperoleh persentase $\mathrm{SiO}_{2}$ meningkat dan $\mathrm{Al}_{2} \mathrm{O}_{3}$ menurun. Nilai rasio $\mathrm{Si} / \mathrm{Al}$ dari zeolit berbasis silika SCBA lebih rendah dari zeolit berbasis silika LUDOX dikarenakan Al yang berpartisipasi relatif lebih banyak, karena $\mathrm{Al}$ sudah tergabung dalam satu kerangka dengan Si pada silika SCBA. Zeolit berbasis LUDOX membutuhkan $\mathrm{NaAlO}_{2}$ sebagai sumber aluminanya karena silika LUDOX tidak mengandung Al.

Analisis nitrogen sorption isotherms dengan metode BET dapat menentukan luas permukaan spesifik, volume pori dan diameter pori zeolit MOR (Zhu et al. 2011). Analisis ini dapat membuktikan bahwa kedua zeolit MOR yang disintesis merupakan zeolit pori hirarki. Grafik isoterm dari adsorpsi-desorpsi nitrogen pada zeolit MOR (LUDOX) dan MOR (SCBA) ditunjukkan pada Gambar 7.

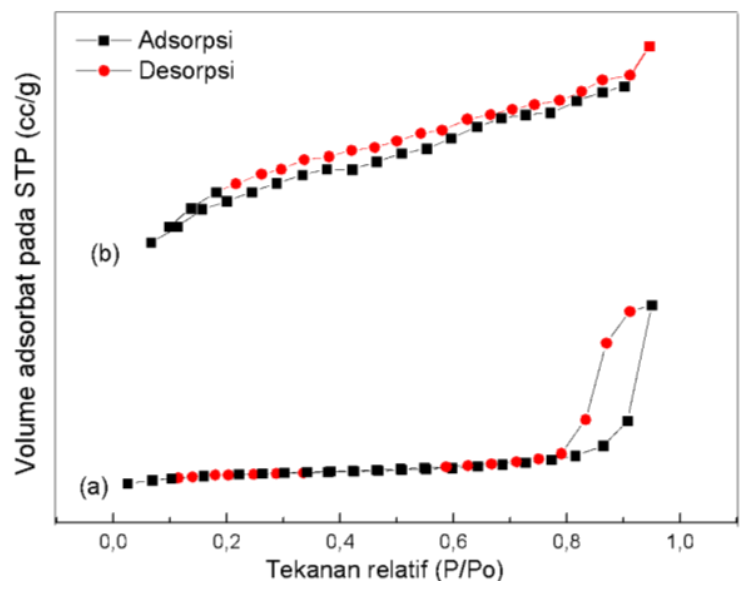

Gambar 7. Grafik isotermis zeolit MOR berbahan dasar (a) silika LUDOX (b) silika SCBA.

Gambar 7 menunjukkan grafik jumlah adsorpsi nitrogen terhadap tekanan relative P/Po dan dapat dilihat bahwa grafik isotermis adsorpsi-desorpsi nitrogen oleh zeolit MOR berbahan silika LUDOX dan silika SCBA merupakan isoterm tipe IV (adsorpsi padatan mesopori) yang ditunjukkan oleh adanya histeresis loop. Grafik isotermis dari zeolit MOR LUDOX terjadi histeresis loop pada P/Po sekitar 0,80 sampai 0,95 sedangkan zeolit MOR SCBA sekitar 0,22 sampai 0,62. Zeolit pori hirarki merupakan zeolit berpori mikro $(<1 \mathrm{~nm})$ dengan adanya tambahan 
mesopori $(2-50 \mathrm{~nm})$, sehingga zeolit pori hirarki memiliki pori tambahan berskala meso (>2 $\mathrm{nm})$ (Rilyanti et al. 2016; Kadja et al. 2016). Berdasarkan data analisis nitrogen sorption isoterms, zeolit MOR berbasis silika LUDOX memiliki luas permukaan spesifik 22,26 $\mathrm{m}^{2} / \mathrm{g}$ dengan volume pori berukuran $1,18 \mathrm{cc} / \mathrm{g}$ dan pori tambahan berukuran rata-rata 7,86 $\mathrm{nm}$. Zeolit MOR berbasis silika SCBA memiliki luas permukaan spesifik $20,93 \mathrm{~m}^{2} / \mathrm{g}$ dengan volume pori berukuran 0,25 $\mathrm{cc} / \mathrm{g}$ dan pori tambahan rata-rata 4,83 $\mathrm{nm}$. Hasil tersebut mengindikasikan bahwa telah berhasil disintesis MOR pori hirarki berbasis silika komersil dan silika abu ampas tebu.

\section{KESIMPULAN}

Ekstraksi silika dari SCBA telah berhasil dilakukan menggunakan pelarut alkali $(\mathrm{NaOH})$, berdasarkan hasil analisis XRD yang menunjukkan silika berfasa amorf. Rasio Si/Al pada silika SCBA yaitu 3,51 dari kandungan silika sebesar 85,552\% dan alumina sebesar $12,162 \%$. Zeolit MOR pori hirarki berbasis silika komersial (LUDOX) dan silika SCBA telah berhasil disintesis menggunakan metode SSC yang ditunjukkan dengan adanya puncak khas zeolit MOR dengan bentuk morfologi kristal tak beraturan. Hasil analisis nitrogen sorption isoterms dengan metode BET, kedua zeolit tersebut memiliki pola isoterm tipe IV dengan ukuran pori sebesar 7,86 untuk MOR LUDOX dan 4,83 nm untuk MOR SCBA.

\section{UCAPAN TERIMA KASIH}

Penulis mengucapkan terima kasih kepada Lembaga Penelitian dan Pengabdian kepada Masyarakat Unila yang telah mendanai penelitian ini dalam skim Penelitian Unggulan Universitas Lampung 2019 kontrak no. 2230/UN26.21/PN/2019 dan Unit Pelaksana Teknis Laboratorium Terpadu dan Sentra Inovasi Teknologi (UPT LTSIT) Universitas Lampung untuk analisis SEM dan FTIR.

\section{DAFTAR PUSTAKA}

Alfaro, S., M. A. Valenzuela, and P. Bosch. 2009. Synthesis of silicalite-1 by dry-gel conversion method: Factors affecting its crystal size and morphology. Journal of Porous Materials 16 (3):337-342.

Cao, G., and M. J. Shah. 2007. In situ monitoring of zeolite crystallization by electrical conductivity measurement: New insight into zeolite crystallization mechanism. Microporous and Mesoporous Materials 101 (1-2):19-23. 
Chen, L. H., X. Y. Li, J. C. Rooke, Y. H. Zhang, X. Y. Yang, Y. Tang, F. S. Xiao, and B. L. Su. 2012. Hierarchically structured zeolites: Synthesis, mass transport properties and applications. Journal of Materials Chemistry 22 (34):17381-17403.

Cheng, X., J. Mao, X. Lv, T. Hua, X. Cheng, Y. Long, and Y. Tang. 2014. Fast synthesis of nanosized zeolite beta from a low-seeded, lowlated dry gel with a seeding-steam-assisted conversion method. Journal of Materials Chemistry A 2 (5):1247-1251.

Gao, W., C. C. Amoo, G. Zhang, M. Javed, B. Mazonde, C. Lu, R. Yang, C. Xing, and N. Tsubaki. 2019. Insight into solvent-free synthesis of MOR zeolite and its laboratory scale production. Microporous and Mesoporous Materials 280:187-194.

Hajiha, H., M. Sain, O. Faruk, and M. Sain. 2015. 17 - The use of sugarcane bagasse fibres as reinforcements in composites. In Biofiber Reinforcements in Composite Materials: Woodhead Publishing, 525-549.

Jin, Y., Y. Li, S. Zhao, Z. Lv, Q. Wang, X. Liu, and L. Wang. 2012. Synthesis of mesoporous MOR materials by varying temperature crystallizations and combining ternary organic templates. Microporous and Mesoporous Materials 147 (1):259-266.

Kadja, G. T. M., R. R. Mukti, Z. Liu, M. Rilyanti, Ismunandar, I. N. Marsih, M. Ogura, T. Wakihara, and T. Okubo. 2016. Mesoporogen-free synthesis of hierarchically porous ZSM-5 below 100Â $\hat{\mathrm{A}}^{\circ} \mathrm{C}$. Microporous and Mesoporous Materials 226:344-352.

Mois Ã@s, M. P., P. P. de Almeida, C. T. P. da Silva, A. W. Rinaldi, E. M. Girotto, J. G. Meneguin, P. A. Arroyo, R. E. Bazan, S. L. FÃ $j$ varo, and E. Radovanovic. 2014. Synthesis of zeolite from multilayer food packing and sugar cane bagasse ash for $\mathrm{CO} 2$ adsorption. RSC Advances 4 (89):48576-48581.

Norsuraya, S., H. Fazlena, and R. Norhasyimi. 2016. Sugarcane Bagasse as a Renewable Source of Silica to Synthesize Santa Barbara Amorphous-15 (SBA-15). Procedia Engineering 148:839-846.

Paix ̃̃£o, V., A. P. Carvalho, J. o. Rocha, A. Fernandes, and A. Martins. 2010. Modification of MOR by desilication treatments: Structural, textural and acidic characterization. Microporous and Mesoporous Materials 131 (1):350-357.

PayÃ $i$, J., J. Monz $\tilde{A}^{3}$, M. Š. Borrachero, L. DÃ-az-Pinz $\tilde{A}^{3} n$, and L. Š. Ord $\tilde{A}^{3} \tilde{A} \pm$ ez. 2002. Sugarcane bagasse ash (SCBA): studies on its properties for reusing in concrete production, 321325.

Perkebunan, S. D. S. T. 2017. Statistik Tebu Indonesia.

Rilyanti, M., R. R. Mukti, G. T. M. Kadja, M. Ogura, H. Nur, E.-P. Ng, and Ismunandar. 2016. On the drastic reduction of organic structure directing agent in the steam-assisted crystallization of zeolite with hierarchical porosity. Microporous and Mesoporous Materials 230:30-38.

doi: http://dx.doi.org/10.23960/aec.v5.i2.2020.p178-191

Anal.Environ.Chem. 
Wang, Q., J. Wang, Y. Zhou, and X. Lin. 2013. Synthesis of framework-substituted Co-mordenite by dry gel conversion. Journal of Porous Materials 20 (6):1519-1523.

Wang, Y., J. Song, N. C. Baxter, G.-T. Kuo, and S. Wang. 2017. Synthesis of hierarchical ZSM-5 zeolites by solid-state crystallization and their catalytic properties. Journal of Catalysis 349:53-65.

Worathanakul, P., W. Payubnop, and A. Muangpet. 2009. Characterization for Post-treatment Effect of Bagasse Ash for Silica Extraction. International Journal of Chemical and Molecular Engineering 3 (8):398-400.

Zhou, J., Z. Hua, J. Shi, Q. He, L. Guo, and M. Ruan. 2009. Synthesis of a hierarchical micro/mesoporous structure by steam-assisted post-crystallization. Chemistry - A European Journal 15 (47):12949-12954.

Zhou, M., A. A. Rownaghi, and J. Hedlund. 2013. Synthesis of mesoporous ZSM-5 zeolite crystals by conventional hydrothermal treatment. RSC Advances 3 (36):15596-15599.

Zhu, Y., Z. Hua, J. Zhou, L. Wang, J. Zhao, Y. Gong, W. Wu, M. Ruan, and J. Shi. 2011. Hierarchical mesoporous zeolites: Direct self-assembly synthesis in a conventional surfactant solution by kinetic control over the zeolite seed formation. Chemistry - A European Journal 17 (51):14618-14627. 